Volume 13

Issue 3 Critical Genocide and Atrocity

Prevention Studies

$12-20-2019$

\title{
Book Review: Hitler's Atrocities against Allied PoWs: War Crimes of the Third Reich
}

Timothy Heck

King's College, London

Follow this and additional works at: https://digitalcommons.usf.edu/gsp

\section{Recommended Citation}

Heck, Timothy (2019) "Book Review: Hitler's Atrocities against Allied PoWs: War Crimes of the Third Reich," Genocide Studies and Prevention: An International Journal: Vol. 13: Iss. 3: 163-165.

DOI:

https://doi.org/10.5038/1911-9933.13.3.1681

Available at: https://digitalcommons.usf.edu/gsp/vol13/iss3/13

This Book Review is brought to you for free and open access by the Open Access Journals at Digital Commons @ University of South Florida. It has been accepted for inclusion in Genocide Studies and Prevention: An International Journal by an authorized editor of Digital Commons @ University of South Florida. For more information, please contact digitalcommons@usf.edu. 


\title{
Book Review: Hitler's Atrocities against Allied PoWs: War Crimes of the Third Reich
}

\author{
Timothy Heck \\ King's College London \\ London, England
}

Hitler's Atrocities against Allied PoWs: War Crimes of the Third Reich

Philip D. Chinnery

Yorkshire, Pen \& Sword Military, 2018

327 Pages; Price: $£ 25$ Hardcover

Reviewed by Timothy Heck

King's College, London

The Nuremberg trials following World War II brought to light the extensive crimes committed by the German National Socialist regime against civilian and military populations. German violations of the Geneva Prisoner-of-War Convention of 1929 were revealed to be commonplace during the war. Currently, the British Government's official position is that German violations of the Geneva Convention were spontaneous events. Philip D. Chinnery, in Hitler's Atrocities against Allied PoWs: War Crimes of the Third Reich, attempts to prove they were indeed centrally authorized by Berlin. This is not Chinnery's first work on prisoners of war. He has also authored two books on Allied prisoners of war during World War II and another on Chinese and North Korean-perpetrated war crimes during the Korean War (1950-3). While the events recounted are emotionally fraught and no doubt war crimes, the book suffers from a variety of structural and research deficiencies which makes the book of limited value to academics and impedes its ability to accomplish its objective.

German atrocities against British and Commonwealth prisoners are the work's central focus. Chinnery was previously the historian and chairman of the National Ex-Prisoner of War Association. As he states in his introduction, "this book has been written to help set the record straight and to try to educate those in the government who should know better." ${ }^{1}$ Specifically, those who should know better are the British politicians who denied an appeal for monetary compensation to survivors of German prisoner of war camps. By contrast, former prisoners of the Japanese were awarded compensation by those same politicians Chinnery seeks to persuade.

The individualized effort in recounting the fate and tale of British POWs is impactful. The victims are not nameless but rather are revealed to be individuals. Whether massacre survivors, escapees, or downed aviators, Chinnery presents these men as men of honor and individuals against whom the moral repugnance of the German military was visited.

The book is organized into sixteen chapters, plus an appendix, glossary and index. The chapters are largely arranged chronologically. Several chapters are thematic, including a chapter on atrocities against Soviet prisoners of war, the murders of downed airmen, and life in the prisoner of war camps. The appendix consists of two transcriptions of British War Office documents regarding punishment of German war criminals.

The book starts with Germany's invasion of Poland. Several massacres in Poland are covered, including the Soviet-perpetrated Katyn Forest Massacre. Oddly, the book does not explicitly state in the text that the Soviets executed these Polish prisoners. Readers will find that listed under an unsourced photograph at the end of the chapter. This chapter also includes a section on how the German government treated its own citizens found guilty of small acts of kindness to the Polish prisoners turned laborers in the Reich.

The book's British focus begins in Chapter Two where Chinnery lays out several massacres and executions of surrendered British prisoners by German units and individuals. The next few chapters are also focused on British and Commonwealth prisoners taken in North Africa, the

${ }^{1}$ Phillip D. Chinnery, Hitler's Atrocities against Allied PoWs: War Crimes of the Third Reich (Yorkshire: Pen \& Sword Military, 2018), ix. 
Mediterranean, and Italy. The book's longest chapter is dedicated to the commandos executed as a result of the infamous Kommandobefehl ("Commando Order"). When coupled with the twenty-nine pages later dedicated to the deaths of Special Air Service men, the risks faced by captured special operations forces become readily apparent. The book then examines executed airmen, POW camp life, and atrocities committed at D-Day, Arnhem, and during the Battle of the Bulge. Chinnery concludes by looking at the incomplete postwar efforts to bring the perpetrators to justice. Like other chapters, it is largely on British efforts.

Only one chapter, a mere seventeen pages in length, is dedicated to atrocities against Soviet prisoners of war. In the Soviet east, the German Army's "complicity in...ideological warfare is well-established, particularly at the higher levels." ${ }^{2}$ Given the extensive mortality rates among Soviet POWs, estimated between sixty and eighty percent, this chapter should have received further expansion. ${ }^{3}$ The German atrocities on the Eastern Front are not unknown nor unavailable for reference. This chapter's scholarship is cursory, largely relying on the recollections of one British witness. While Chinnery briefly mentions the fate of Jewish Soviet prisoners of war, he does not access texts like Shneyer's Pariahs Among Pariahs: Soviet-Jewish POWs in German Captivity, 1941-1945. ${ }^{4}$ For example, there are no discussions of the Uman pit (Stalag 329) where tens of thousands of Soviet POWs died or of DULAG-205 at Stalingrad. ${ }^{5}$ Additionally, the writing is rife with gross generalizations that detract from the book's value. Soviet POWs are presented as a faceless mass. As an example, Chinnery compares the British and Soviet prison camps as follows. The most noticeable difference between the Russian camp and the British Stalags was a total lack of discipline among the Russians and another difference between the British and Russian camps was the smell. Apparently the Russian idea of personal cleanliness was clearly different to that in the West when he notes that the other inmates were dark, swarthy-looking men from the east.... ${ }^{6}$

Similarly, in a brief section on postwar Soviet justice, the fate of the soldiers of the German 6th Army after its capitulation at Stalingrad is callously referred to as how "German other ranks also paid for their sins." ${ }^{7}$ While there is no doubt the 6th Army committed war crimes during their operations, this post facto judgment of all members of the command is inappropriate in a scholarly work.

The book succeeds in bringing to light some of the atrocities committed against prisoners of war by the German military during World War II. This said, it has three major flaws. First, as discussed above, there is a distinct lack of balance between atrocities committed on the Eastern Front and those against the Western Allies. Secondly, it suffers from a lack of scholarly grounding. While many of the chapters reference research files at the National Archives at Kew, the referencing is done by section rather than inline with the text. The result is anyone seeking to verify Chinnery's sources will have a difficult time replicating the work. Furthermore, there are almost no references to the existing scholarship already done on the subject. Instead of presenting a focused synthesis, the result is a work that seems largely anecdotal in nature. Thirdly, for a book which seeks to persuade the reader of government-wide complicity in the mistreatment of prisoners, the work lacks a strong legal grounding. While Lord Russell of Liverpool, the Deputy Judge Advocate, British Army of the Rhine, is referenced in the book's introduction and conclusions, the lack of other legal sources and findings is an oversight which weakens the argument that the events recounted were not isolated incidents. This absence makes it difficult for the reader to draw the dots between the actions of individuals or units and their political and military leadership in the

\footnotetext{
${ }^{2}$ Jeff Rutherford and Adrian E. Wettstein, The German Army on the Eastern Front: An Inner View of the Ostheer's Experiences of War (Barnsely, UK: Pen \& Sword Military, 2018), 201.

${ }^{3}$ For numbers and mortality estimations, see Reinhard Otto, Rolf Keller, and Jens Nagel, "Sowjetische Kriegsgefangene in deutschem Gewahrsam 1941-1945," Vierteljahrshefte für Zeitgeschichte 56, 4 (2008), 557-602.

${ }^{4}$ Aron Shneyer, Pariahs Among Pariahs: Soviet-Jewish POWs in German Captivity, 1941-1945 (Jerusalem, Israel: Yad Vashem Publications, 2016).

${ }^{5}$ Frank Ellis, "Dulag-205: The German Army's Death Camp for Soviet Prisoners at Stalingrad," The Journal of Slavic Military Studies 19, no. 1 (2006), 123-148.

${ }^{6}$ Chinnery, Hitler's Atrocities against Allied PoWs, 92-93.

${ }^{7}$ Ibid.,102.
} 
absence of documented orders.

Hitler's Atrocities Against Allied PoWs cannot be regarded as an academic study of the fate awaiting captured Allied servicemen and women. Its narrow focus, socio-political goal, and limited engagement with the historiography prevent it from serving as more than a survey text or springboard. Rather, the book's value is largely an emotional one. Chinnery attempts to tie the individual fates to a larger argument that the German armed forces and their security force compatriots were systematically responsible for the abuses described in the book. While the individual cases are compelling and some, like the executions that took place under the Kommandobefehl, have a clear connection to explicit policies, the book does not succeed in linking its other examples to a larger line of reasoning. 